\title{
Article \\ Evaluation of Pig Manure for Environmental or Agricultural Applications through Gasification and Soil Leaching Experiments
}

\author{
Despina Vamvuka * and Adamantia Raftogianni
}

check for updates

Citation: Vamvuka, D.; Raftogianni,

A. Evaluation of Pig Manure for

Environmental or Agricultural

Applications through Gasification

and Soil Leaching Experiments. Appl.

Sci. 2021, 11, 12011. https://doi.org/

10.3390/app112412011

Academic Editor: Vincenza Ferraro

Received: 22 November 2021

Accepted: 14 December 2021

Published: 16 December 2021

Publisher's Note: MDPI stays neutral with regard to jurisdictional claims in published maps and institutional affiliations.

Copyright: (c) 2021 by the authors. Licensee MDPI, Basel, Switzerland. This article is an open access article distributed under the terms and conditions of the Creative Commons Attribution (CC BY) license (https:/ / creativecommons.org/licenses/by/ $4.0 /)$.
School of Mineral Resources Engineering, Technical University of Crete, 73100 Chania, Greece; araftogianni@isc.tuc.gr

* Correspondence: vamvuka@mred.tuc.gr

\begin{abstract}
The current study aimed at evaluating an untreated pig manure, firstly for its suitability for soil amendment in combination with an agricultural/bio-solid biochar, and secondly for its potential to be used for adsorption of hazardous species, replacing expensive activated carbons. Column soil leaching experiments were designed to simulate field conditions, and physical, chemical and mineralogical analyses were performed for raw materials and/or leachates. For activated carbon production, the manure was gasified by steam or carbon dioxide at high temperatures. Biochars were analyzed for organic and mineral matter, structural characteristics and organic functional groups. Activation by steam or carbon dioxide greatly enhanced specific surface area, reaching values of 231.4 and $233.3 \mathrm{~m}^{2} / \mathrm{g}$, respectively. Application of manure to the soil promoted leaching of nitrates and phosphates and raised COD values of water extracts. Biochar addition retained these ions and reduced COD values up to 10 times at the end of the three-month period. The concentrations of heavy metals in the leachates were low and, in the presence of biochar in soil blends, they were significantly reduced by $50-70 \%$. The manure presents a significant potential for adsorption of various pollutants or improvement of soil amendment if carefully managed.
\end{abstract}

Keywords: manure; leaching; soil; biochar; gasification; active carbon

\section{Introduction}

Animal wastes such as manure, a low-value byproduct of livestock feedlots, are readily available in large quantities in most countries around the world, including those of South Europe. In Greece, where animal breeding activity is highly developed, about $41 \mathrm{Mm}^{3}$ of animal wastes is produced annually [1] and stocked outside animal processing industries or in rural areas, causing environmental pollution. Thus, traditional land application is no longer a viable solution. EU directives 1991/31/EC and 1991/676/EC imposed a reduction in the quantity of biodegradable wastes going to landfill.

The use of animal manure as a fertilizer reduces the volume of wastes and ameliorates the physical, chemical and biological properties of soil, providing various nutrients for plant growth [2,3]. However, the process of composting can change the properties of manure and, if not carefully managed, can cause eutrophication or contamination of soil and water sources [3-5]. The limitations imposed by the composting process have turned scientific attention to investigate the blending of composts with other wastes, to potentially improving the availability of nutrients and leaching of toxic heavy metals in soils [6-10]. Such wastes may be agricultural residues, which are particularly abundant in Mediterranean countries, and contain significant concentrations of $\mathrm{Ca}, \mathrm{Mg}$ and $\mathrm{K}$ [5], in addition to urban bio-solids, which are rich in N, Ca, P and Fe [11]. All of these elements are important for improving soil fertility. In Greece, about 3.8 $\mathrm{M}$ dry tons of agricultural residues are produced annually [12], whereas about $30 \mathrm{~kg} /$ capita/year of dry bio-solids [11] are produced from wastewater treatment plants. 
As an alternative to soil application, animal manures can be converted to added-value products through thermal treatment. Pyrolysis destroys pathogens from these wastes [5], and generates bio-oil and gas, which provide useful energy $[13,14]$, and a carbon rich and porous material, biochar, which is of high interest. In addition to its potential to be used as fuel, as a carbon sink in soils for thousands of years, or as soil fertilizer [15-18], biochar may exhibit similar properties as activated carbons, adsorbing various contaminants from soil and waste waters, such as heavy metals [19-21] and organic pollutants [17,22,23]. These properties, such as specific surface area, pore structure and organic functional groups, can be enhanced by physical or chemical activation $[17,24]$, providing a bio-carbon of higher reactivity and lack of tar in the product gas [25]. Physical activation without using chemical reagents, such as alkali or acids, is more environmentally friendly and has a lower cost. When steam is used, the calorific value of the product gas is enhanced, whereas when carbon dioxide from residual flue gases is the activation agent, the process offers a potential solution to the greenhouse gas problem, avoiding its capture and sequestration [24,25]. Therefore, physical activation by steam or carbon dioxide is both environmentally and economically more advantageous. The final properties of biochar depend on the raw material and the conditions of the thermal process $[5,13,14]$.

A large number of studies have been undertaken relevant to soil amendment using composts $[3,4,26,27]$ or biochars $[7,9,10,13,26-29]$ from various biomass materials (agricultural wastes, sewage sludge). Co-application of composts from animal manure and woody biochars has been less investigated (pig slurry/wood chips compost and rice husk biochar [2], chicken manure/straw compost and empty palm fruit biochar [6], pig manure/straw compost and maize straw biochar [23], horse and rabbit manure/grass, fruits, seaweed compost and oak wood biochar [30]). Reported results include reduction in heavy metals [2] and nutrients mobility [6] and bio-availability of organic pollutants [23] from contaminated soils, in addition to suppression of plant-parasitic nematodes [6]. However, combined utilization of untreated manure with mixtures of agricultural/bio-solid biochars is scarce (dairy cattle manure with hardwood biochar [31], swine manure with corn straw biochar [32]) and examines microbial respiration, fungi/bacteria abundance, and uptake of nitrogen and phosphorous upon bioleaching. Furthermore, generation of potential activated carbons has focused on agricultural wastes [33-35] and there is limited information in the literature on animal manure biochar activated by steam or carbon dioxide [24].

In the context of sustainable recycling of animal manures, meeting the policies of the EU on the environment and the circular economy [11] and based on the previous discussion, the current study aimed at evaluating an untreated pig manure, firstly for its suitability for soil amendment in combination with an agricultural/bio-solid biochar and secondly for its potential to be used for adsorption of hazardous species, replacing expensive activated carbons. The first objective was to conduct column soil leaching experiments, designed to simulate field conditions for a three-month period, and measure the concentrations of nutrients or toxic substances in water extracts. Physical, chemical and mineralogical analyses were performed for raw materials and/or leachates. The second objective was to produce a biochar material from manure for use as an adsorbent, through pyrolysis and subsequent activation by either steam or carbon dioxide at high temperatures. Each biochar was analyzed for organic and mineral matter, structural characteristics and organic functional groups.

\section{Materials and Methods}

\subsection{Raw Materials Characterization}

The manure (MAS) was provided from a swine breeding factory in the region of Rethymno-Crete. Before being used in the experiments, it was passed through a riffler in order to obtain representative samples and then sieved to particle sizes $<500 \mu \mathrm{m}$. The soil used for the leaching tests was sampled from the top $20 \mathrm{~cm}$ of the area of Chania-Crete, following the rectangular grid method. After riffling and sieving to a particle size $<2 \mathrm{~mm}$, it was subjected to physical, mineralogical and chemical analyses. In these tests, two biomass 
materials were also used: cotton stems (COS) provided by a ginning factory in Central Greece and a bio-solid (BIS) from the waste water treatment plant of the city of Chania. These were air-dried, ground to a particle size of $<500 \mu \mathrm{m}$ (cotton stems in a cutting mill, bio-solid in a ball mill) and riffled.

European standards CEN/TC335 were adopted for the characterization of raw materials in terms of proximate (moisture, volatile matter, fixed carbon, ash) and ultimate $(\mathrm{C}, \mathrm{H}$, $\mathrm{N}, \mathrm{S}, \mathrm{O}$ ) analyses. An X-ray diffractometer (XRD), model A8 Advance of Bruker AXS, was employed for the detection and identification of mineral phases in ashes, by DIFFRAC plus Evaluation software in conjunction with the JCPDS database. Chemical analysis in major elements was conducted by an X-ray fluorescence spectrometer, model S2 Ranger/EDS of Bruker AXS.

\subsection{Biochar Production and Activation}

The equipment used for the production of biochars, through pyrolysis experiments in nitrogen, was a high temperature fixed bed unit, described in detail in a previous work [5]. In a typical test, about $15 \mathrm{~g}$ of sample was placed in a stainless steel grid basket supported by a rod and inserted into the reactor. The unit was assembled, introduced into the furnace and flushed with nitrogen for $30 \mathrm{~min}$ at room temperature. The furnace was set to the desired temperature at a heating rate of $10{ }^{\circ} \mathrm{C} / \mathrm{min}$. The temperature was measured by a $\mathrm{Ni}-\mathrm{Cr}-\mathrm{Ni}$ thermocouple, in contact with the sample bed. The flow rate of nitrogen during pyrolysis was $150 \mathrm{~mL} / \mathrm{min}$ and the retention time at the final temperature $30 \mathrm{~min}$. Volatile products were passed through iso-propanol cooled by ice-baths, to collect condensables. The system was cooled under nitrogen and the resultant biochar was weighed and stored for further tests.

In the case of adsorption experiments, the manure was pyrolyzed at 700 or $800{ }^{\circ} \mathrm{C}$. Following pyrolysis, manure was activated either by steam (flow rate $2500 \mathrm{~mL} / \mathrm{min}$ ), generated by distilled water flowing at $0.5 \mathrm{~mL} / \mathrm{min}$ with a piston pump inside a spiral tube within the furnace, or by carbon dioxide (flow rate $150 \mathrm{~mL} / \mathrm{min}$ ), and was held at the activation temperature for $1 \mathrm{~h}$, before being cooled under nitrogen.

In the case of leaching experiments, cotton stems and bio-solid were pyrolyzed as above, but the final temperature was $350{ }^{\circ} \mathrm{C}$, to maintain important properties for soil amendment $[4,7,9,10,36]$.

Structural characteristics of both pyrolyzed and steam/carbon dioxide-activated manure were determined by an automatic volumetric apparatus, model Nova 2200 of Quantachrome, according to the BET method. Manure sample was out-gassed overnight at $150{ }^{\circ} \mathrm{C}$ under vacuum prior to each test. Furthermore, the chemical functional groups of this material were identified through a spectrophotometer, model Spectrum 100 of Perkin Elmer, recording FTIR spectra at a resolution of $4 \mathrm{~cm}^{-1}$, in the range of $400-4000 \mathrm{~cm}^{-1}$ wavenumbers.

\subsection{Leaching of Manure and Biochars through the Soil}

Soil, manure and biochar (cotton stems/bio-solid 70:30) mixtures were prepared as follows: manure/soil $50 \mathrm{~g} / \mathrm{kg}$, manure/soil $100 \mathrm{~g} / \mathrm{kg}$, biochar/manure/soil $50 \mathrm{~g} / 100 \mathrm{~g} / \mathrm{kg}$ and biochar/manure/soil $100 \mathrm{~g} / 50 \mathrm{~g} / \mathrm{kg}$, representing common application rates of $0-100 \mathrm{t} / \mathrm{ha}$ soil [37]. All mixtures were homogenized in glass pots and kept at $30{ }^{\circ} \mathrm{C}$ in the dark for a one-month period, during which they were wetted with de-ionized water and gently stirred, periodically. After this incubation procedure, simulating agronomic practices for soil amendment, admixed materials were packed into PVC (ID $=2.5 \mathrm{~cm}$, $\mathrm{H}=25 \mathrm{~cm}$ ) columns, fitted with fiberglass and a valve at the base and saturated with de-ionized water. Leaching was discontinuous over a three-month period, simulating as much as possible local rainfall conditions and percolating through each column an amount of de-ionized water corresponding to the average annual quantity of rainfall in the area between the years 2015-2020 (about $600 \mathrm{~mm}$ ). Keeping the hydraulic head constant on the basis of communicating vessels and after collecting enough liquid for the chemical 
analyses, each effluent was filtered through micropore membrane filters several times and kept in acid washed bottles in the refrigerator.

The apparent density of solid materials before and after incubation was measured following the ASTM D-285 method [38], and the water holding capacity was measured following the method proposed by Ye et al. [39]. $\mathrm{pH}$ and electrical conductivity were measured with a pH-meter type Toledo LE438 of Mettler and an EC215 of Hanna, respectively. For solid samples, the solid-to-deionized water ratio was 1:5. A spectrophotometer UV-VIS, model Smart 3 of LaMotte, was used for analyzing leachates in chemical oxygen demand (COD; by the mercury digestion method 0077-SC, measuring range 0-15,000 mg/L), N$\mathrm{NO}_{3}$ (by the zinc reduction method 3689-SC, measuring range $0-60 \mathrm{mg} / \mathrm{L}$ ), $\mathrm{P}-\mathrm{PO}_{4}$ (by the vanadomolybdophosphoric acid method $3655-\mathrm{SC}$, measuring range $0-90 \mathrm{mg} / \mathrm{L}$ ) and phenols (by the aminoantipyrine method 3652-SC, measuring range 0-6 mg/L). Analysis of trace elements in leachates was performed by an inductively coupled plasma mass spectrometer, model ICP-MS 7500cx of Agilent Technologies, assisted by an Anton Paar Multiwave 3000 oven, for samples' digestion.

\section{Results and Discussion}

\subsection{Chemical and Mineralogical Properties of Raw Materials}

A comparison of proximate and ultimate analyses of the raw materials studied is represented in Table 1. All samples were rich in volatiles. Cotton stems had the highest volatile matter content, fixed carbon and oxygen contents, and the lowest ash, nitrogen and sulfur concentrations. By comparison, the ash content of manure was high, whereas its carbon, hydrogen and oxygen contents were lower among the other materials. However, the amounts of sulfur and particularly nitrogen of manure and bio-solid samples were significant, revealing gaseous emissions during thermal treatment, but also increased capacity for plant nutrition when applied to soils for amelioration.

Table 1. Proximate and ultimate analysis of raw materials (\% dry).

\begin{tabular}{ccccccccc}
\hline Sample & Volatiles & Fixed Carbon & Ash & C & H & N & O & S \\
\hline Manure (MAS) & 51.9 & 16.5 & 31.6 & 35.8 & 5.3 & 3.6 & 22.2 & 1.5 \\
Cotton stems (COS) & 73.4 & 18.3 & 8.3 & 46.8 & 6.5 & 1.6 & 36.7 & 0.2 \\
Bio-solid (BIS) & 65.6 & 16.6 & 17.8 & 43.0 & 6.6 & 7.9 & 22.9 & 1.8 \\
\hline
\end{tabular}

Figure 1 illustrates the XRD spectra of the samples. The soil was of quarzitic nature, with small amounts of muscovite and chlorite minerals. The manure was rich in $\mathrm{Ca}, \mathrm{Mg}, \mathrm{P}$ and Fe phases, such as calcite, dolomite, whitlockite magnesian, hematite and rodolicoite. $\mathrm{P}$ was also incorporated in hydroxyapatite, whereas $\mathrm{K}$ was found in fairchildite. The bio-solid consisted mainly of whitlockite magnesian and considerable amounts of $\mathrm{Ca}$ and Fe bound in calcite, hematite and kennedyte. The cotton stems sample was dominated by $\mathrm{K}$ and $\mathrm{Mg}$, in the forms of sylvite, arcanite and dolomite, respectively, and to a smaller extent by Ca identified in carbonates, phosphates and aluminosilicates.

The concentrations of the major elements in manure and biochars, represented in Figure 2, are in accordance with the XRD analysis discussed above. Regarding nutrients, the higher quantities of $\mathrm{Ca}$ and $\mathrm{Mg}$ were measured in manure, the higher amounts of $\mathrm{P}$ and Fe were measured in the bio-solid, and those of $\mathrm{K}$ were measured in cotton stems biochar. These concentrations are comparable to those of similar materials reported by previous investigations $[13,18,28]$. However, it must be noted that the solubility of the minerals incorporating these nutrients governs their bio-availability in soils $[18,28]$. 


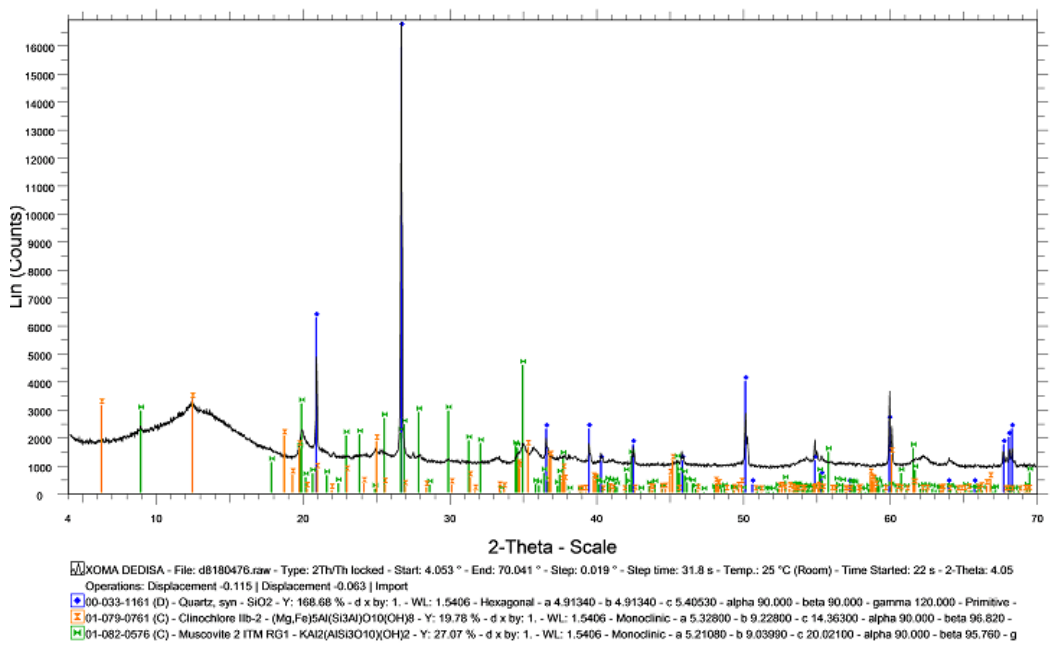

(a)

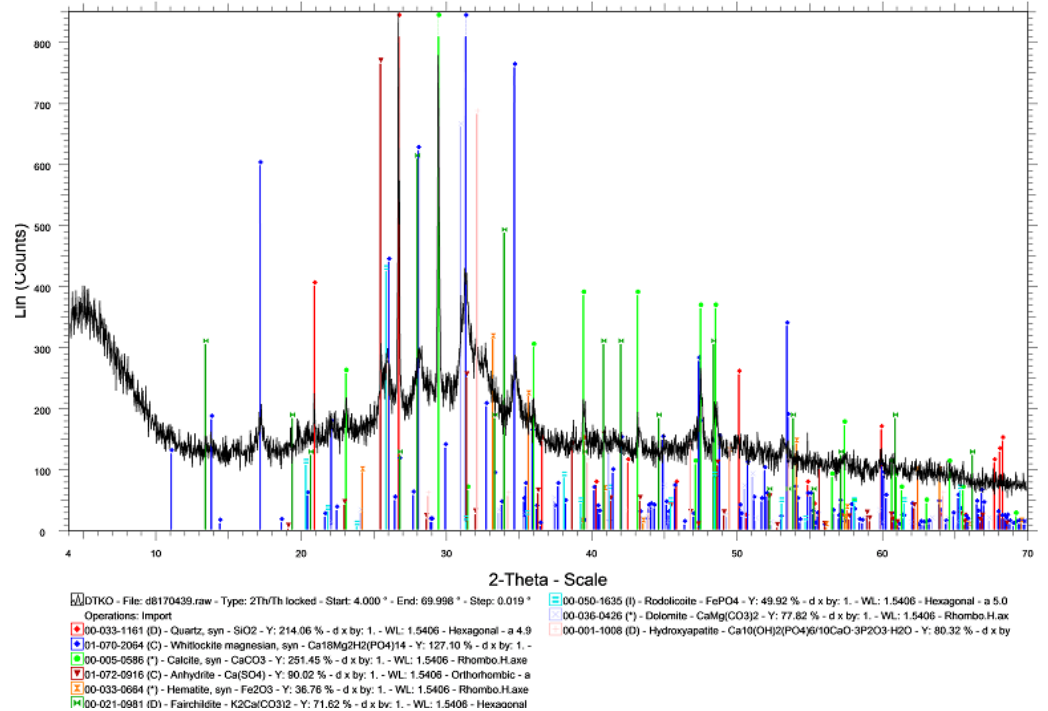

(b)

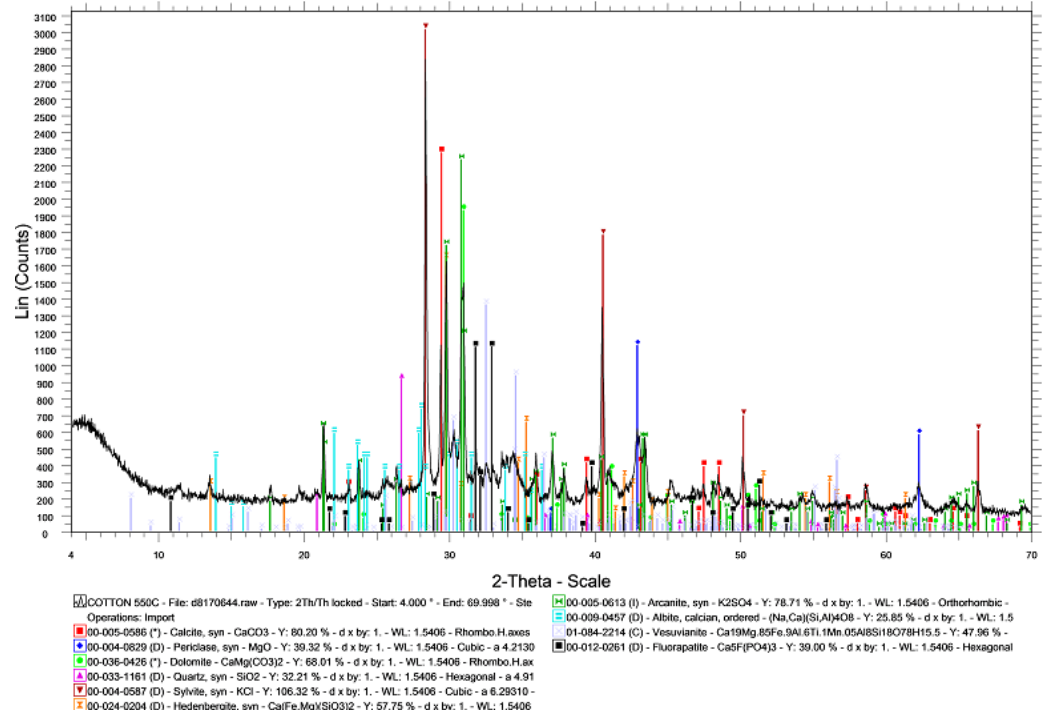

(c)

Figure 1. Cont. 


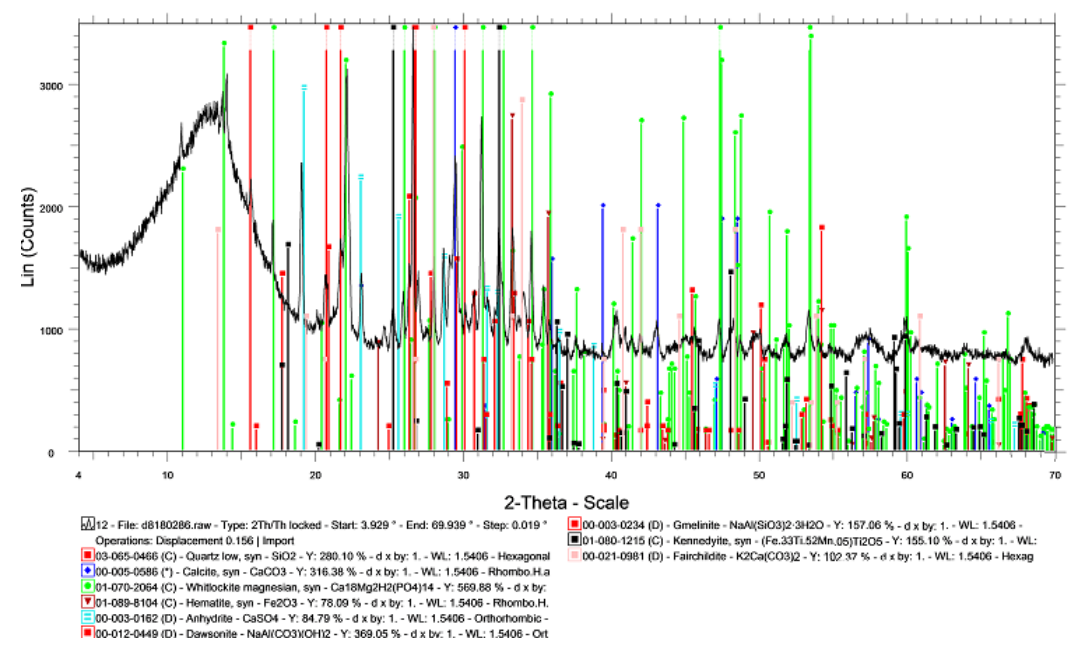

(d)

Figure 1. XRD spectra of (a) soil, (b) pig manure, (c) cotton stems, (d) bio-solid ashes.

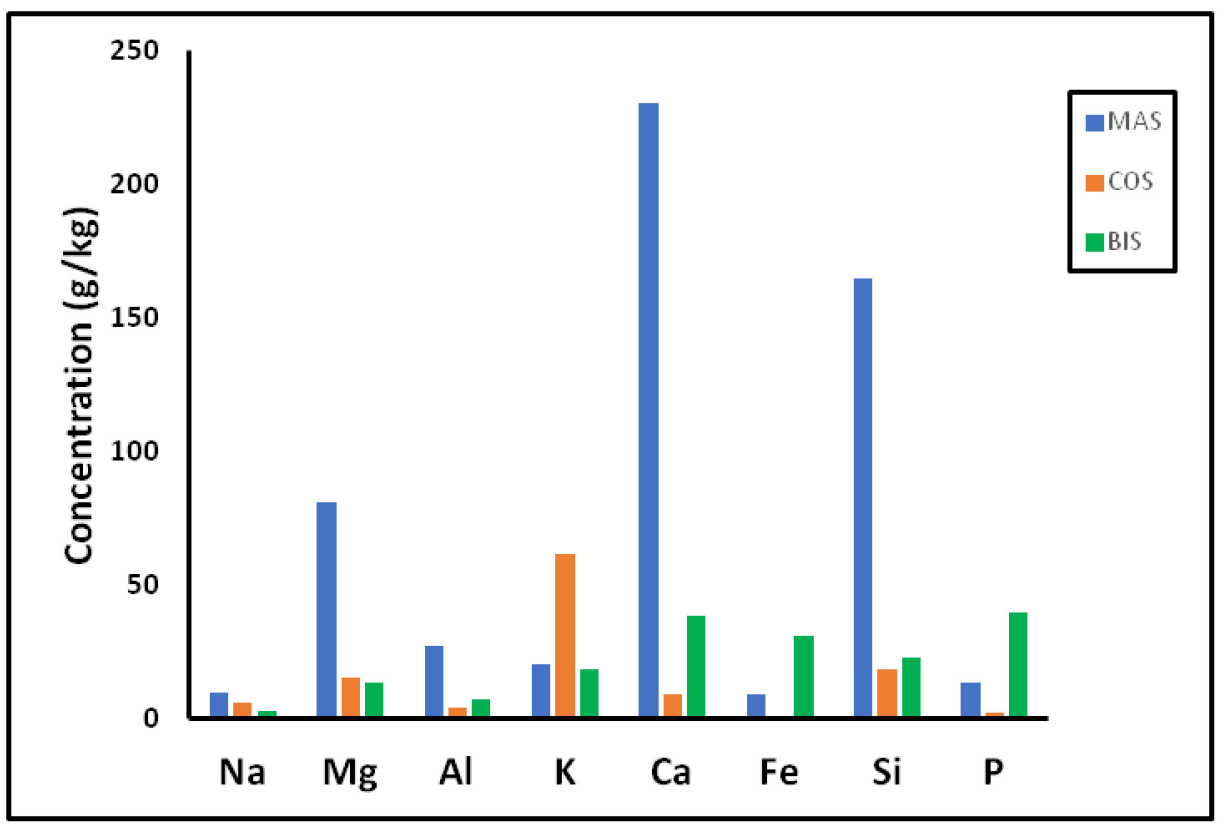

Figure 2. Concentration of major elements in pig manure, cotton stems and bio-solid biochars.

\subsection{Physical Activation of Manure}

\subsubsection{Yield of Products under Different Atmosphere}

The yield of solid products of pyrolysis under nitrogen and of those activated by gasification under steam or carbon dioxide, as a function of temperature, is compared in Figure 3. As can be seen, when the pyrolyzed material was activated with either steam or carbon dioxide, the yield of biochar was lower with respect to pyrolysis only and the drop was higher in the presence of steam. In a previous work by the authors, it was found that the higher reactivity of steam was due to favored reactions of the oxygen organic functional groups of biochar, whereas carbon dioxide disrupted the hydrogen char structure [35]. Moreover, a higher activation temperature led to the production of less biochar, due to enhanced thermal decomposition of manure and secondary cracking of vapors. The proportions of bio-oil and gas (not shown in Figure 3) varied between 37.5\% and $9.5-12.5 \%$, respectively, at $700{ }^{\circ} \mathrm{C}$, and between $24.6 \%$ and $27.5-41.6 \%$, respectively at $800{ }^{\circ} \mathrm{C}$, with higher heating values $20-40 \mathrm{MJ} / \mathrm{kg}$ for bio-oil and $11-15 \mathrm{MJ} / \mathrm{m}^{3}$ for 
gas [40]. These values were considered highly satisfactory for the energy requirements of the pyrolysis/gasification unit.

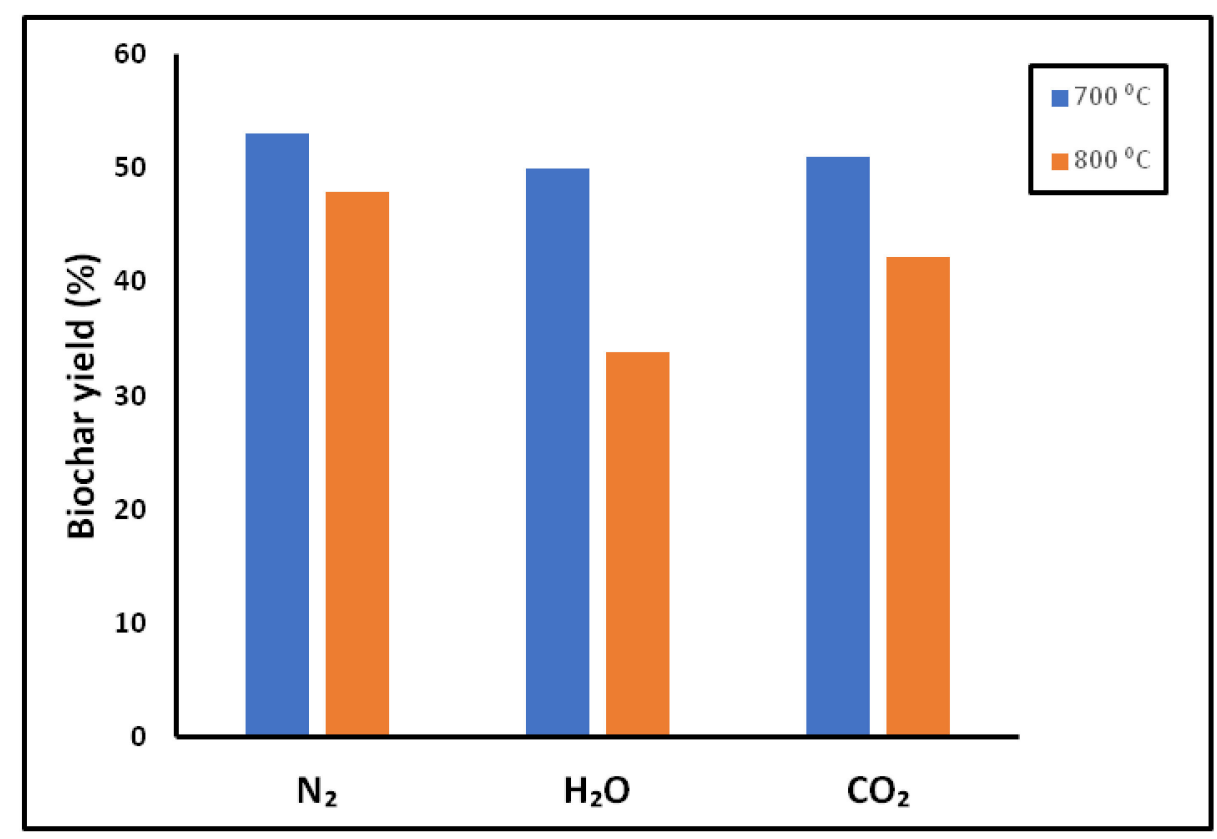

Figure 3. Yield of biochar under $\mathrm{N}_{2}, \mathrm{H}_{2} \mathrm{O}_{\mathrm{v}}$ or $\mathrm{CO}_{2}$ atmosphere as a function of temperature.

3.2.2. Structural Characteristics and Chemical Functional Groups under Different Atmosphere

The structural characteristics of manure biochar produced after pyrolysis with nitrogen or combined pyrolysis-gasification with steam or carbon dioxide are summarized in Table 2. As can be seen, a rise in pyrolysis temperature from 700 to $800{ }^{\circ} \mathrm{C}$, associated with a greater decomposition and release of volatile products, elevated pore volume and size and increased the surface area by $45 \%$. Nevertheless, the value of $69 \mathrm{~m}^{2} / \mathrm{g}$ was quite low, most probably due to the high ash content of manure biochar, which can hinder the access of nitrogen to the pores. Previous investigations have reported $[19,22,24,41,42]$ even lower surface areas of $2.4-17 \mathrm{~m}^{2} / \mathrm{g}$ at $500{ }^{\circ} \mathrm{C}$ and $8.3 \mathrm{~m}^{2} / \mathrm{g}$ at $700{ }^{\circ} \mathrm{C}$.

Table 2. Structural characteristics of manure biochar produced after pyrolysis/gasification.

\begin{tabular}{|c|c|c|c|c|}
\hline Temperature $\left({ }^{\circ} \mathrm{C}\right)$ & Activation Gas & $\begin{array}{c}\text { Specific } \\
\text { Surface Area }\left(\mathrm{m}^{2} / \mathrm{g}\right)\end{array}$ & $\begin{array}{c}\text { Micropore } \\
\text { Volume } \times 10^{2}\left(\mathrm{~cm}^{3} / \mathrm{g}\right)\end{array}$ & $\begin{array}{c}\text { Average } \\
\text { Pore Size }(\AA)\end{array}$ \\
\hline \multirow{2}{*}{700} & $\mathrm{~N}_{2}$ & 47.6 & 4.4 & 37.0 \\
\hline & $\mathrm{H}_{2} \mathrm{O}_{\mathrm{v}}$ & 231.4 & 15.9 & 33.0 \\
\hline \multirow{3}{*}{800} & $\mathrm{~N}_{2}$ & 68.9 & 5.9 & 49.3 \\
\hline & $\mathrm{H}_{2} \mathrm{O}_{\mathrm{v}}$ & 228.7 & 21.5 & 45.1 \\
\hline & $\mathrm{CO}_{2}$ & 233.3 & 16.2 & 33.3 \\
\hline
\end{tabular}

When manure biochar was further activated with steam at $700{ }^{\circ} \mathrm{C}$, it is clearly shown that micropore volume and surface area were greatly enhanced 4.9-fold, reaching a value of $231.4 \mathrm{~m}^{2} / \mathrm{g}$. At the higher temperature of $800^{\circ} \mathrm{C}$, microporosity increased, in addition to the size of the pores, which are characterized as mesopores. By comparison, upon activation of manure biochar with carbon dioxide at $800^{\circ} \mathrm{C}$, microporosity was developed, the average pore size was smaller and specific surface area was elevated 3.4-fold, reaching a value of $233.3 \mathrm{~m}^{2} / \mathrm{g}$. Some authors reported [24] a further increase in microporosity and specific surface area at a higher temperature, $900{ }^{\circ} \mathrm{C}$, enabling a value of $700 \mathrm{~m}^{2} / \mathrm{g}$ to be attained. 
From the above results, taking into consideration the yield and surface area of manure biochar activated by either steam or carbon dioxide at 700 and $800^{\circ} \mathrm{C}$, it can be inferred that this material presents a significant potential for adsorption of various inorganic or organic contaminants and it is promising for further investigation.

Table 3 compares the chemical functional groups identified [43] from the FTIR spectra of the manure sample produced under nitrogen, steam and carbon dioxide activation at $800{ }^{\circ} \mathrm{C}$. The Pyrolyzed material represented $\mathrm{C}=\mathrm{C}$ alkene groups at $666 \mathrm{~cm}^{-1}$, whereas C-O sharp peaks in the range $1000-1400 \mathrm{~cm}^{-1}$ are associated with alcohols and ethers. Peaks at 1454,1650 and $1714 \mathrm{~cm}^{-1}$ are characteristic of $\mathrm{C}-\mathrm{H}, \mathrm{C}=\mathrm{C}$ and $\mathrm{C}=\mathrm{O}$ stretching vibration bands from alkanes, alkenes and carboxylic acids, respectively, and were also identified in a previous study [24]. Smaller bands in the range $2000-2400 \mathrm{~cm}^{-1}$ correspond to $\mathrm{O}=\mathrm{C}=\mathrm{O}$ stretching, whereas those in the range $2500-3000 \mathrm{~cm}^{-1}$ are assigned to $\mathrm{C}-\mathrm{H}$ deforming vibration from aldehydes or alkanes. Finally, the broad band between 3000 and $4000 \mathrm{~cm}^{-1}$ indicates the presence of $-\mathrm{OH}$ stretching groups from alcohols or carboxylic acids. FTIR spectra are generally in agreement with those obtained for different manure biochar samples [22,41].

Table 3. FTIR analysis of manure biochar produced under nitrogen, steam, or carbon dioxide.

\begin{tabular}{|c|c|c|c|}
\hline Wavenumber $\left(\mathrm{cm}^{-1}\right) /$ Functional Groups & $\mathbf{N}_{2}$ & $\mathrm{H}_{2} \mathrm{O}$ & $\mathrm{CO}_{2}$ \\
\hline \multirow[t]{2}{*}{ 500-600/C-X halo compounds } & & 556 & 564 \\
\hline & & 592 & 592 \\
\hline \multirow{6}{*}{$\begin{array}{l}1000-1400 / \mathrm{C}-\mathrm{O} \text { alcohols, ethers } \\
1000\end{array}$} & 666 & & \\
\hline & 1046 & 1030 & 1036 \\
\hline & 1114 & 1090 & \\
\hline & 1146 & & \\
\hline & 1156 & & \\
\hline & 1234 & & \\
\hline $\begin{array}{c}1300-1600 / \mathrm{C}-\mathrm{H} \text { alkanes, } \mathrm{C}=\mathrm{C} \text { aromatic } \\
\text { compounds }\end{array}$ & 1454 & 1550 & 1440 \\
\hline $1600-1670 / C=C$ alkenes & 1650 & & 1602 \\
\hline $1650-1750 / \mathrm{C}=\mathrm{O}$ carboxylic acids & 1714 & & \\
\hline \multirow[t]{2}{*}{$2000-2400 / \mathrm{O}=\mathrm{C}=\mathrm{O}$ carbon dioxide } & 2318 & & \\
\hline & 2350 & & \\
\hline \multirow{2}{*}{ 2500-3000/C-H aldehydes, alkanes } & 2848 & & \\
\hline & 2918 & & \\
\hline 3000-4000/-OH alcohols, carboxylic acids & 3292 & & 3436 \\
\hline
\end{tabular}

When the material was activated by steam, Table 3 shows that, in addition to the small peaks at $500-600 \mathrm{~cm}^{-1}$ corresponding to C-X stretching from halo compounds, a new broad peak appeared at $1550 \mathrm{~cm}^{-1}$, indicating the presence of $\mathrm{C}=\mathrm{C}$ stretching from aromatic compounds. No peaks were detected at higher wave numbers (Figure 4). By comparison, in the case of carbon dioxide activation, an additional broad band was identified at $3436 \mathrm{~cm}^{-1}$, characteristic of $-\mathrm{OH}$ stretching from alcohols, implying that the aromaticity of char was higher in the presence of steam.

\subsection{Leachability of Manure Blends through the Soil}

\subsubsection{Physicochemical Properties before and after Incubation}

The physicochemical properties of manure and cotton stems/bio-solid biochar, with different combinations before and after the incubation period, are represented in Table 4. The most important properties that affect the leachability of nutrients and heavy metals from soil, in addition to the retention of moisture by soil and, consequently, plant growth, are the $\mathrm{pH}$ and the water holding capacity of the solid materials, respectively. As can be noted, before incubation all solid mixtures were slightly alkaline $(\mathrm{pH}=7.6-7.8)$ with small electrical conductivity values $(1.05-1.1 \mathrm{mS} / \mathrm{cm})$, properties which positively influence soil amelioration $[4,32]$. After incubation, there was a small drop in $\mathrm{pH}$ and a marked 
decrease in electrical conductivity, revealing that some alkaline salts were released, leaving a solid material with a higher potential for uptake of nutrients or water by plants upon soil application [4]. This is strengthened by the fact that after incubation the volume (density decrease) and the water holding capacity of all blends, especially those containing the biochar, were increased (d was decreased up to $42 \%$ and WHC was increased up to $30 \%$ ), improving absorption of water by soil.

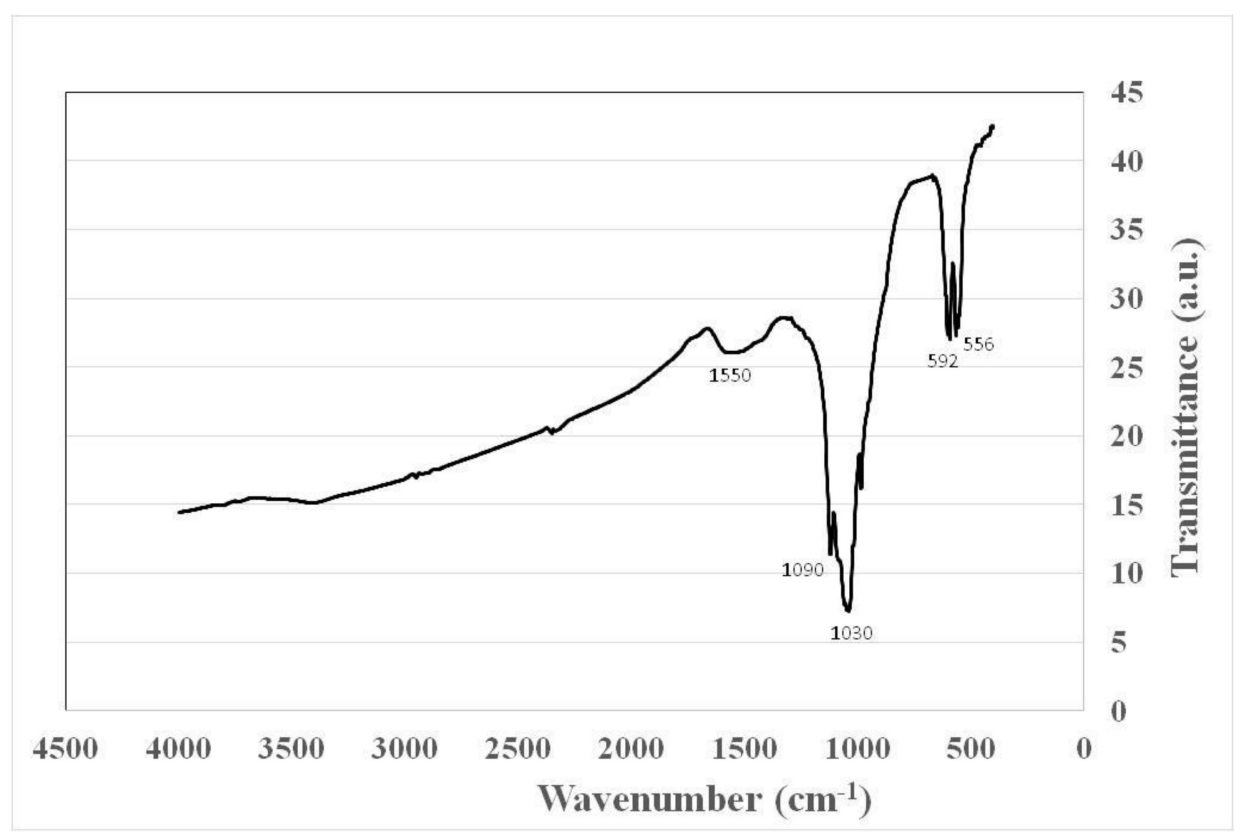

Figure 4. FTIR spectra of pig manure biochar activated by steam at $800{ }^{\circ} \mathrm{C}$.

Table 4. Physicochemical properties of solid blends.

\begin{tabular}{|c|c|c|c|c|c|c|c|c|}
\hline \multirow[b]{2}{*}{ Sample } & \multicolumn{4}{|c|}{ Before Incubation } & \multicolumn{4}{|c|}{ After Incubation } \\
\hline & $\underset{\left(\mathrm{g} / \mathrm{cm}^{3}\right)}{\mathrm{d}}$ & $\mathrm{pH}$ & $\begin{array}{c}\mathrm{EC} \\
(\mathrm{mS} / \mathrm{cm})\end{array}$ & $\begin{array}{l}\text { WHC } \\
(g / g)\end{array}$ & $\underset{\left(\mathrm{g} / \mathrm{cm}^{3}\right)}{d}$ & $\mathrm{pH}$ & $\begin{array}{c}\mathrm{EC} \\
(\mathrm{mS} / \mathrm{cm})\end{array}$ & $\begin{array}{l}\text { WHC } \\
(g / g)\end{array}$ \\
\hline Soil & 1.06 & 7.80 & 1.05 & 0.92 & & & & \\
\hline MAS/soil $50 \mathrm{~g} / \mathrm{kg}$ & 1.02 & 7.70 & 1.10 & 0.94 & 1.0 & 6.35 & 0.20 & 1.0 \\
\hline MAS/soil $100 \mathrm{~g} / \mathrm{kg}$ & 1.01 & 7.60 & 1.10 & 0.94 & 0.63 & 6.30 & 0.40 & 1.0 \\
\hline $\begin{array}{l}\text { COS-BIS/MAS/soil } \\
50 \mathrm{~g} / 100 \mathrm{~g} / \mathrm{kg}\end{array}$ & 1.01 & 7.68 & 1.06 & 0.94 & 0.64 & 6.38 & 0.45 & 1.18 \\
\hline $\begin{array}{c}\text { COS-BIS/MAS/soil } \\
100 \mathrm{~g} / 50 \mathrm{~g} / \mathrm{kg}\end{array}$ & 1.0 & 7.79 & 1.05 & 0.94 & 0.61 & 6.41 & 0.20 & 1.20 \\
\hline
\end{tabular}

\subsubsection{Leaching of Nitrogen, Phosphorous Anions and Phenols}

The leaching behavior of nitrogen and phosphorous anions and phenols with time from the soil/manure/biochar mixtures, together with the variation of $\mathrm{pH}$ and electrical conductivity in the leachates, is illustrated in Table 5. Addition of a higher amount of manure to the soil $(100 \mathrm{~g} / \mathrm{kg}$ instead of $50 \mathrm{~g} / \mathrm{kg})$ reduced the $\mathrm{pH}$ of the first water extract from 8.1 to 6.2. In both cases, the $\mathrm{pH}$ became neutral after a three-month period (7.1 in the case of MAS/soil $50 \mathrm{~g} / \mathrm{kg}$ and 7.2 in the case of MAS/soil $100 \mathrm{~g} / \mathrm{kg}$ ). However, the more biochar was added ( $100 \mathrm{~g} / \mathrm{kg}$ of COS-BIS, instead of $50 \mathrm{~g} / \mathrm{kg}$ ), the higher was the $\mathrm{pH}$ of the leachates (up to 8.5), due to the dissolution of some alkaline substances from biochar, such as carbonates of $\mathrm{Ca}, \mathrm{Mg}$ and $\mathrm{K}$ (calcite, dolomite and fairchildite seen in Figure 1). Moreover, Table 5 shows that some readily soluble salts were released from the soil/manure blend in the first leachate, increasing the electrical conductivity values $(2.8 \mathrm{mS} / \mathrm{cm}$ in the case of MAS/soil $50 \mathrm{~g} / \mathrm{kg}$ and $4.9 \mathrm{mS} / \mathrm{cm}$ in the case of MAS/soil 
$100 \mathrm{~g} / \mathrm{kg}$ ). In the presence of COS-BIS biochar, these values dropped significantly and were very low after 22 days leaching time $(0.4-1 \mathrm{mS} / \mathrm{cm})$. As previously mentioned, a higher $\mathrm{pH}$ and a lower electrical conductivity favor availability of nutrients for plants.

Table 5. Leaching of ions and phenols from solid mixtures.

\begin{tabular}{|c|c|c|c|c|c|c|}
\hline Sample & $\begin{array}{l}\text { Leaching } \\
\text { Time (days) }\end{array}$ & $\mathrm{pH}$ & $\begin{array}{c}\mathrm{EC} \\
(\mathrm{mS} / \mathrm{cm})\end{array}$ & $\begin{array}{l}\mathrm{NO}_{3}^{-} \\
(\mathrm{mg} / \mathrm{L})\end{array}$ & $\begin{array}{l}\mathrm{PO}_{4}{ }^{3-} \\
(\mathrm{mg} / \mathrm{L})\end{array}$ & $\begin{array}{c}\text { Phenols } \\
\text { (mg/L) }\end{array}$ \\
\hline \multirow{6}{*}{$\begin{array}{l}\text { MAS/soil } \\
50 \mathrm{~g} / \mathrm{kg}\end{array}$} & 1 & 8.1 & 2.8 & 26 & 6 & \multirow{6}{*}{1.7} \\
\hline & 8 & 8.1 & 0.8 & 45 & 31 & \\
\hline & 22 & 7.5 & 0.9 & 38 & 33 & \\
\hline & 36 & 7.4 & 1.0 & 32 & 34 & \\
\hline & 60 & 7.2 & 0.6 & 25 & 36 & \\
\hline & 90 & 7.1 & 0.4 & 20 & 40 & \\
\hline \multirow{6}{*}{$\begin{array}{l}\text { MAS/soil } \\
100 \mathrm{~g} / \mathrm{kg}\end{array}$} & 1 & 6.2 & 4.9 & 43 & 62 & \multirow{6}{*}{2.4} \\
\hline & 8 & 6.4 & 3.6 & 42 & 69 & \\
\hline & 22 & 6.5 & 2.3 & 41 & 75 & \\
\hline & 36 & 6.7 & 1.1 & 40 & 82 & \\
\hline & 60 & 7.0 & 0.7 & 30 & 85 & \\
\hline & 90 & 7.2 & 0.4 & 21 & 89 & \\
\hline \multirow{6}{*}{$\begin{array}{c}\text { COS- } \\
\text { BIS/MAS/soil } \\
50 \mathrm{~g} / 100 \mathrm{~g} / \mathrm{kg}\end{array}$} & 1 & 6.8 & 2.6 & 27 & 21 & \multirow{6}{*}{2.9} \\
\hline & 8 & 7.1 & 2.1 & 26 & - & \\
\hline & 22 & 7.4 & 1.5 & 25 & - & \\
\hline & 36 & 7.7 & 1.0 & 24 & - & \\
\hline & 60 & 7.8 & 1.0 & 20 & - & \\
\hline & 90 & 7.8 & 1.0 & 17 & - & \\
\hline \multirow{6}{*}{$\begin{array}{c}\text { COS- } \\
\text { BIS/MAS/soil } \\
100 \mathrm{~g} / 50 \mathrm{~g} / \mathrm{kg}\end{array}$} & 1 & 8.5 & 3.8 & 22 & 5 & \multirow{6}{*}{1.7} \\
\hline & 8 & 7.9 & 1.4 & 20 & - & \\
\hline & 22 & 7.8 & 0.7 & 17 & - & \\
\hline & 36 & 7.6 & 0.6 & 13 & - & \\
\hline & 60 & 7.5 & 0.5 & 10 & - & \\
\hline & 90 & 7.5 & 0.4 & 7 & - & \\
\hline
\end{tabular}

Regarding the concentration of $\mathrm{NO}_{3}{ }^{-}$in effluents, from Table 5 it can be seen that this was higher in the case of soil/manure mixtures $(21-45 \mathrm{mg} / \mathrm{L})$ and decreased with leaching time. However, upon addition of COS-BIS biochar to the mixture some retention of nitrate ions occurred (concentration in leachates $7-27 \mathrm{mg} / \mathrm{L}$ ), revealing either their adsorption on biochar surface, or nitrogen binding in heterocyclic compounds that were not easily solubilized [18]. According to previous research [44], this retention can improve the uptake of manure nitrogen by plants. Furthermore, Table 5 clearly indicates that no phosphates were released in the presence of biochar in the solid blends, in accordance with the insoluble whitlockite magnesian in biochar (Figure 1). Phosphate ions measured in the soil/manure leachates $(6-89 \mathrm{mg} / \mathrm{L})$ were most probably associated with the hydroxyapatite mineral identified in the manure sample (Figure 1). Therefore, the extractability of phosphate ions was mainly correlated with the mineral phases, in which phosphorous was incorporated. Field experiments, however, may provide more relevant information. Finally, the quantity of extracted phenols in all cases was low $(1.7-2.9 \mathrm{mg} / \mathrm{L})$.

The decrease in COD with leaching time for all solid mixtures is represented in Figure 5. As can be observed, COD values of soil/manure mixtures were higher than soil/manure/biochar mixtures, but also exceeded literature data reported for other manure samples [45]. Once biochar was admixed to the above mixture, COD was reduced up to 10 times at the end of the three-month period. It has been reported [45] that oxygen-rich biochars, such as that in the study (Table 1), can adsorb organic and inorganic species on their surface from the soil/water system, leading to lower COD values in water extracts. 


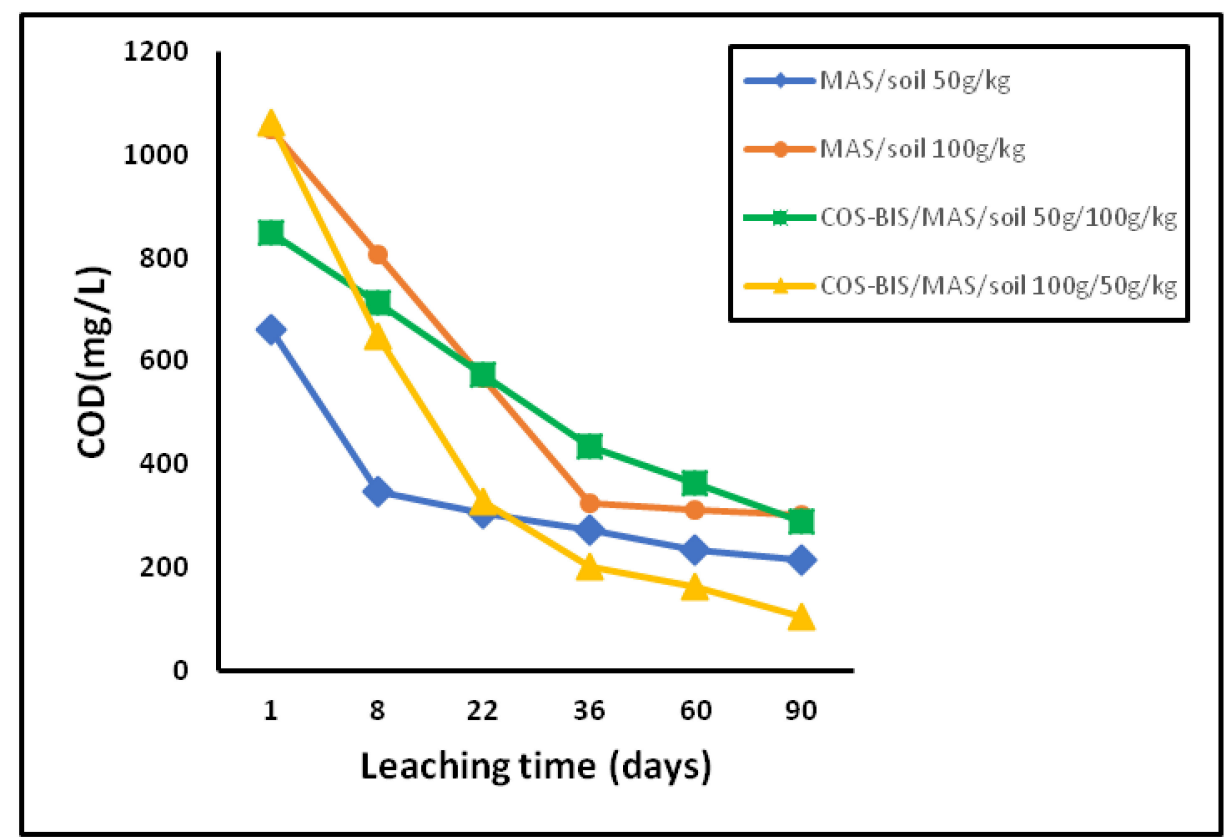

Figure 5. Variation of COD with time in biochar/manure/soil leachates.

\subsubsection{Leaching of Metals}

Figure 6 compares the release of major elements from all soil combinations in the leachates. The application of manure to the soil increased significantly the amounts of $\mathrm{Ca}$ and $\mathrm{Mg}$ dissolved in water, principally attributed to the high contents of soluble calcite and dolomite minerals in manure (Figure 1). Upon addition of biochar, it can be seen that the extractability of $\mathrm{Ca}$ was reduced, suggesting that the surface or porosity of biochar provided retention sites for this element. By comparison, the leachability of $\mathrm{K}$ was greatly intensified with a higher amount of biochar, due to the high concentrations of the soluble forms of sylvite and arcanite in this (Figure 1).

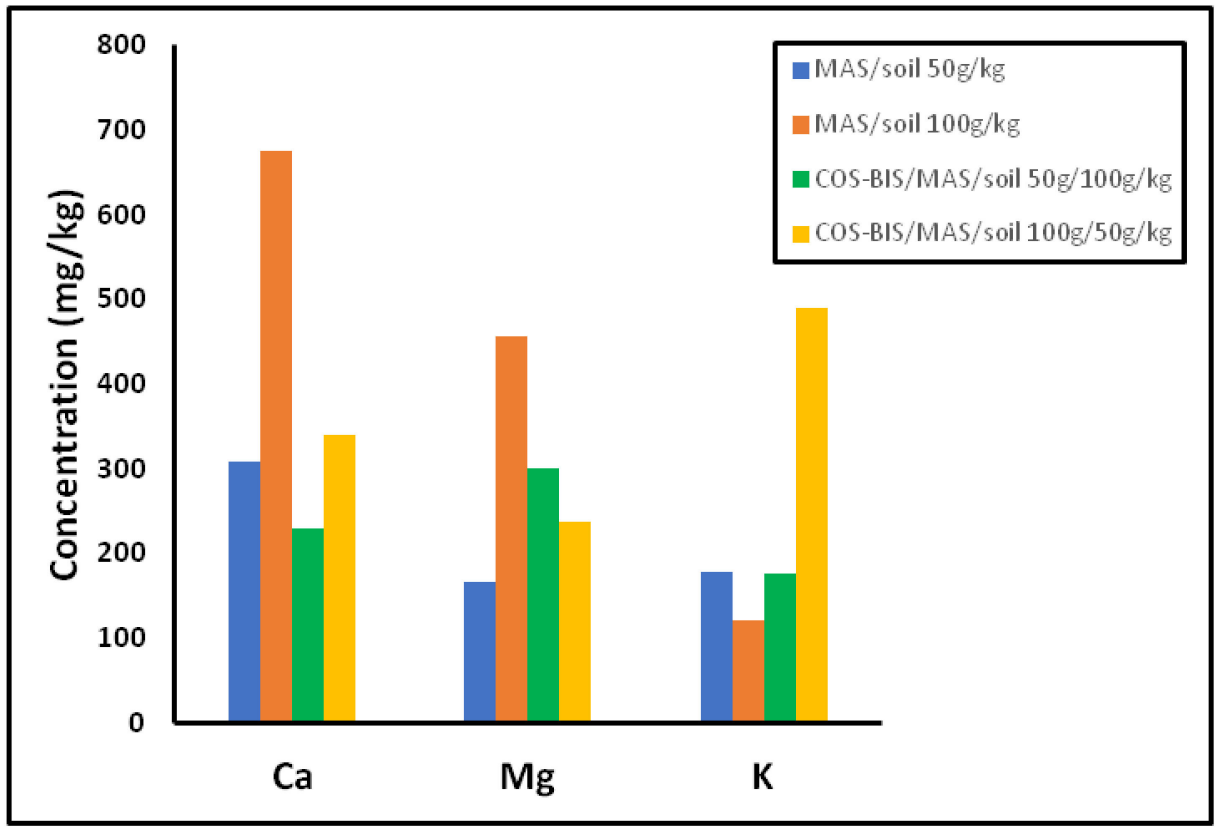

Figure 6. Cumulative concentration of major elements in biochar/manure/soil leachates.

Regarding the leaching behavior of heavy metals from the materials studied, Table 6, presenting the cumulative concentrations in liquid effluents, indicates that only $\mathrm{Sr}, \mathrm{Zn}$ and 
Mn were extracted in considerable amounts, of 413-1145, 145-487 and 215-462 $\mu \mathrm{g} / \mathrm{kg}$, respectively. The higher extractability of $\mathrm{Sr}$ suggests that this element was associated with organic matter, or salts dissolved in the water effluents [5]. In the presence of biochar in the mixtures, heavy metal levels in the leachates were significantly reduced by about $50-70 \%$ (Cu by $50 \%$, Mn by $54 \%$, Sr by $64 \%$, Zn by $70 \%$ ). Toxic metals $\mathrm{Cr}, \mathrm{Co}, \mathrm{Hg}$ and As were not quantified at all in the extracts, being below detection limits, and $\mathrm{Pb}$, which is known to have calcium or organic affinity [11], was very low, implying no risk to the environment. All measured values were below the legislation limits of EC [46]. Possible reasons for the low leachability of metals from the biochar may be their bounding in stable oxides, phosphates or aluminosilicates, such as quartz, hematite, whitlockite magnesian, albite and vezouvian (Figure 1), or other mechanisms, including electrostatic attraction, competition between elements or complexation [47].

Table 6. Cumulative concentrations of trace elements in the leachates ( $\mu \mathrm{g} / \mathrm{kg})$.

\begin{tabular}{ccccc}
\hline Sample & $\begin{array}{c}\text { MAS/Soil } \\
\mathbf{5 0} \mathbf{g} / \mathbf{k g}\end{array}$ & $\begin{array}{c}\text { MAS/Soil } \\
\mathbf{1 0 0} \mathbf{g} / \mathbf{k g}\end{array}$ & $\begin{array}{c}\text { COS- } \\
\text { BIS/MAS/Soil } \\
\mathbf{5 0} \mathbf{~ g / 1 0 0 ~} \mathbf{~} / \mathbf{k g}\end{array}$ & $\begin{array}{c}\text { COS- } \\
\text { BIS/MAS/Soil } \\
\mathbf{1 0 0} \mathbf{g} / \mathbf{5 0} \mathbf{~ g / k g}\end{array}$ \\
\hline $\mathrm{Mn}$ & - & 461.8 & 214.6 & - \\
$\mathrm{Ni}$ & - & 89.3 & 136.0 & - \\
$\mathrm{Cu}$ & 92.0 & 111.1 & 119.8 & 137.8 \\
$\mathrm{Zn}$ & - & 487.0 & 144.8 & - \\
$\mathrm{Sr}$ & 504.5 & 1144.9 & 413.3 & 703.4 \\
$\mathrm{~Pb}$ & 7.3 & - & - & 4.0 \\
\hline
\end{tabular}

\section{Conclusions}

When manure biochar was activated with either steam or carbon dioxide at high temperatures, the yield was lower with respect to pyrolysis only and the drop was greater in the presence of steam. Activation by steam at $700{ }^{\circ} \mathrm{C}$ greatly enhanced the specific surface area by 4.9 -fold, reaching a value of $231.4 \mathrm{~m}^{2} / \mathrm{g}$, whereas at $800{ }^{\circ} \mathrm{C}$ favored enlargement of pores and increased the aromaticity of char. Activation by carbon dioxide at $800{ }^{\circ} \mathrm{C}$ favored microporosity and elevated the specific surface area by 3.4 -fold, reaching a value of $233.3 \mathrm{~m}^{2} / \mathrm{g}$.

Incubation of manure/biochar blends improved soil properties, by lowering significantly the electrical conductivity and increasing the water holding capacity. Application of manure to the soil promoted leaching of nitrates and phosphates, and raised COD values of water extracts. Biochar addition retained these ions and reduced COD values by up to 10 times at the end of the three-month period. The extractability of $\mathrm{Ca}$ and $\mathrm{Mg}$ nutrients was higher from the manure/soil mixture, whereas that of $\mathrm{K}$ was higher upon co-application of biochar. The concentrations of heavy metals in the leachates were low and below legislation limits. In the presence of biochar in soil blends they were significantly reduced, by $50-70 \%$.

Overall, the manure material studied presented a significant potential for adsorption of various pollutants and, if carefully managed and admixed with biochar produced from different wastes, may improve soil amendment for agricultural applications.

Author Contributions: Conceptualization, D.V.; software, A.R.; investigation, D.V. and A.R.; writingreview, D.V. All authors have read and agreed to the published version of the manuscript.

Funding: This research received no external funding.

Institutional Review Board Statement: Not applicable.

Informed Consent Statement: Not applicable.

Data Availability Statement: This study did not report any data. 
Acknowledgments: Permission obtained. The authors kindly thank the laboratories of Hydrocarbons Chemistry and Technology, Ore Processing and Beneficiation and Hydrogeochemical Engineering and Soil Remediation for specific chemical analyses.

Conflicts of Interest: The authors declare no conflict of interest.

\section{References}

1. Hoogwijk, M.; Faaj, A.; Van den Broek, R.; Berndes, G.; Gielen, D.; Turkenburg, W. Exploration of the ranges of the global potential of biomass for energy. Biomass Bioenergy 2003, 25, 119. [CrossRef]

2. Liang, J.; Yang, Z.; Tang, L.; Zeng, G.; Yu, M.; Li, X.; Luo, Y. Changes in heavy metal mobility and availability from contaminated wetland soil remediated with combined biochar-compost. Chemosphere 2017, 181, 281-288. [CrossRef] [PubMed]

3. Cambier, P.; Michaud, A.; Paradelo, R.; Germain, M.; Mercier, V.; Guerin-Lebourg, A.; Houot, S. Trace metal availability in soil horizons amended with various urban waste composts during 17 years-Monitoring and modeling. Sci. Total Environ. 2019, 651, 2961-2974. [CrossRef] [PubMed]

4. Gondek, K.; Mierzwa-Hersztek, M.; Kopec, M. Mobility of heavy metals in sandy soil after application of composts produced from maize straw, sewage sludge and biochar. J. Environ. Manag. 2018, 210, 87-95. [CrossRef]

5. Vamvuka, D.; Sfakiotakis, S.; Pantelaki, O. Evaluation of gaseous and solid products from the pyrolysis of waste biomass blends for energetic and environmental applications. Fuel 2019, 236, 574-582. [CrossRef]

6. Cao, Y.; Gao, Y.; Qi, Y.; Li, J. Biochar-enhanced composts reduce the potential leaching of nutrients and heavy metals and suppress plant-parasitic nematodes in excessively fertilized cucumber soils. Environ. Sci. Pollut. Res. 2018, 25, 7589-7599. [CrossRef]

7. Li, F.; Wu, X.; Ji, W.; Gui, X.; Chen, Y.; Zhao, J.; Zhou, C.; Ren, T. Effects of pyrolysis temperature on properties of swine manure biochar and its environmental risks of heavy metals. J. Anal. Appl. Pyrolysis 2020, 152, 104945. [CrossRef]

8. Qin, X.; Guo, S.; Zhai, L.; Pan, J.; Khoshnevisan, B.; Wu, S.; Wang, H.; Yang, B.; Ji, J.; Liu, H. How long-term excessive manure application affects soil phosphorous species and risk of phosphotous loss in fluvo-aquic soil. Environ. Pollut. 2020, 266, 115304. [CrossRef]

9. Zhang, P.; Zhang, X.; Li, Y.; Han, L. Influence of pyrolysis temperature on chemical speciation, leaching ability and environmental risk of heavy metals in biochar derived from cow manure. Biores. Technol. 2020, 302, 122850. [CrossRef]

10. Xu, Y.; Qu, W.; Sun, B.; Peng, K.; Zhang, X.; Xu, J.; Gao, F.; Yan, Y.; Bai, T. Effects of added calcium-based additives on swine manure derived biochar characteristics and heavy metals immobilization. Waste Manag. 2021, 123, 69-79. [CrossRef]

11. Vamvuka, D.; Papaioannou, G.; Alexandrakis, S.; Stratakis, A. Control of the mobility of heavy metals in soil from disposal of bio-solid and olive by-roduct ashes using waste additives. Environ. Pollut. 2020, 266, 115136. [CrossRef]

12. Vamvuka, D. Biomass, Bioenergy and the Environment, 1st ed.; Tziolas Publications: Salonica, Greece, 2009.

13. Manolikaki, I.; Mangolis, A.; Diamantopoulos, E. The impact of biochars prepared from agricultural residues on phosphorous release and availability in two fertile soils. J. Environ. Manag. 2016, 181, 536-543. [CrossRef]

14. Vamvuka, D.; Sfakiotakis, S. Thermal behavior and reactivity of swine sludge and olive by-products during co-pyrolysis and co-combustion. Waste Biomass Valoriz. 2019, 10, 1433-1442. [CrossRef]

15. Sadaf, J.; Shah, G.; Shahzad, K.; Ali, N.; Shahid, M.; Ali, S.; Hussain, R.; Ahmed, Z.; Traore, B.; Ismail, I.; et al. Improvements in wheat productivity and soil quality can accomplish by co-application of biochars and chemical fertilizers. Sci. Total Environ. 2017, 608, 715-724. [CrossRef]

16. Varma, A.; Mondal, P. Pyrolysis of sugarcane bagasse in semi batch reactor: Effects of process parameters on product yields and characterization of products. Ind. Crops Prod. 2017, 95, 704-717. [CrossRef]

17. Komnitsas, K.; Zaharaki, D. Morphology of modified biochar and its potential for phenol removal from aqueous solutions. Front. Environ. Sci. 2016, 4, 26. [CrossRef]

18. Vamvuka, D.; Dermitzakis, S.; Pentari, D. Valorization of Meat and Bone Meal through pyrolysis for soil amendment or lead adsorption from wastewaters. Food Bioprod. Process. 2018, 109, 148-157. [CrossRef]

19. Idrees, M.; Batool, S.; Ullah, H.; Hussain, Q.; Al-Wabel, M.; Ahmad, M.; Hussain, A.; Riaz, M.; Ok, Y.; Kong, J. Adsorption and thermodynamic mechanisms of manganese removal from aqueous media bybiowaste-derived biochars. J. Mol. Liq. 2018, 266, 373-380. [CrossRef]

20. Zhang, P.; Zhang, X.; Yuan, X.; Xie, R.; Han, L. Characteristics, adsorption behaviors, Cu(II) adsorption mechanisms by cow manure biochar derived at various pyrolysis temperatures. Biores. Technol. 2021, 331, 125013. [CrossRef]

21. Wang, K.; Peng, N.; Zhao, P.; Chen, M.; Deng, F.; Yu, X.; Zhang, D.; Chen, J.; Sun, J. Effect of a low-cost and highly efficient passivator synthesized by alkali-fused fly ash and swine manure on the leachability of heavy metals in a multi-metal contaminated soil. Chemosphere 2021, 279, 130558. [CrossRef]

22. Jiang, B.; Lin, Y.; Mbog, J. Biochar derived from swine manure digestate and applied on the removals of heavy metals and antibiotics. Biores. Technol. 2018, 270, 603-611. [CrossRef] [PubMed]

23. Xiang, L.; Sheng, H.; Gu, C.; Marc, R.; Wang, Y.; Bian, Y.; Jiang, X.; Wang, F. Biochar combined with compost to reduce the mobility, bioavailability and plant uptake of 2,2',4,4'-tetrabrominated diphenyl ether in soil. J. Hazard. Mater. 2019, 374, 341-348. [CrossRef] [PubMed]

24. Zhang, X.; Mao, X.; Pi, L.; Wu, T.; Hu, Y. Adsorptive and capacitive properties of the activated carbons derived from pig manure residues. J. Environ. Chem. Eng. 2019, 7, 103066. [CrossRef] 
25. Vamvuka, D.; Sfakiotakis, S. Gasification reactivity and mass spectrometric analysis of gases of energy crop chars under a $\mathrm{CO}_{2}$ atmosphere. Energy Fuels 2015, 29, 3215-3223. [CrossRef]

26. Prodana, M.; Bastos, A.; Amaro, A.; Cardoso, D.; Morgado, R.; Machado, A.; Verheijen, F.; Keizer, J.; Loureiro, S. Biomonitoring tools for biochar and biochar-compost amended soil under viticulture: Looking at expose and effects. Appl. Soil Ecol. 2019, 137, 120-128. [CrossRef]

27. Badescu, I.; Bulgariu, D.; Bulgariu, L. Alternative utilization of algal biomass (Ulva sp.) loaded with Zn (II) ions for improving of soil quality. J. Appl. Phycol. 2017, 29, 1069-1079. [CrossRef]

28. Limwikran, T.; Kheoruenromne, I.; Suddhiprakarn, A.; Prakongkep, N.; Gilkes, R. Dissolution of K, Ca and P from biochar grains in tropical soils. Geoderma 2018, 312, 139-150. [CrossRef]

29. Ye, S.; Zeng, G.; Wu, H.; Liang, J.; Zhang, C.; Dai, J.; Xiong, W.; Song, B.; Wu, S.; Yu, J. The effects of activated biochar addition on remediation efficiency of co-composting with contaminated wetland soil. Resour. Conserv. Recycl. 2019, 140, 278-285. [CrossRef]

30. Forjan, R.; Rodriguez-Vila, A.; Cerqueira, B.; Covelo, E. Comparison of the effects of compost versus compost and biochar on the recovery of a mine soil by improving the nutrient content. J. Geochem. Explor. 2017, 183, 46-57. [CrossRef]

31. Ippolito, J.; Stromberger, M.; Lentz, R.; Dungan, R. Hardwood biochar and manure co-application to a calcareous soil. Chemosphere 2016, 142, 84-91. [CrossRef]

32. Wei, X.; Liu, D.; Li, W.; Lia, L.; Wang, Z.; Huang, W.; Huang, W. Biochar addition for accelerating bioleaching of heavy metals from swine manure and reserving the nutrients. Sci. Total Environ. 2018, 632, 1553-1559. [CrossRef]

33. Bhushan, B.; Nayak, A.; Kotnala, S. Green synthesis of highly porous activated carbon from jackfruit peel: Effect of operating factors on its physic-chemical characteristics. Mater. Today Proc. 2020, 44, 187-191. [CrossRef]

34. Bubba, M.; Anichini, B.; Bakari, Z.; Bruzzoniti, M.; Camisa, R.; Caprini, C.; Checchini, L.; Fibbi, D.; El Ghadraouia, A.; Liguori, F.; et al. Physicochemical properties and sorption capacities of sawdust-based biochars and commercial activated carbons towards ethoxylated alkylphenols and their phenolic metabolites in effluent wastewater from a textile district. Sci. Total Environ. 2020, 708, 135217. [CrossRef]

35. Vamvuka, D.; Machairas, E.; Sfakiotakis, S.; Pantelaki, O. Physically activated agricultural waste biochars for production of pollutant adsorbents. J. Chem. Eng. Res. Updates 2020, 7, 6-15. [CrossRef]

36. Gong, H.; Tan, Z.; Zhang, L.; Huang, Q. Preparation of biochar with high absorbability and its nutrient adsorption-desorption behavior. Sci. Total Environ. 2019, 694, 133728. [CrossRef]

37. Jeffery, S.; Verheijen, F.; van der Velde, M.; Bastos, A. A quantitative review on the effects of biochar application to soils on crop productivity using meta-analysis. Agric. Ecosyst. Environ. 2011, 144, 175-187. [CrossRef]

38. ASTM. Refractories, activated carbon, advanced ceramics. In ASTM Book of Standards; American Society for Testing Materials: West Conshohocken, PA, USA, 2007; Volume 15.01.

39. Ye, L.; Zhang, J.; Zhao, J.; Luo, Z.; Tu, S.; Yin, Y. Properties of biochar obtained from pyrolysis of bamboo shoot shell. J. Anal. Appl. Pyrolysis 2015, 114, 172-178. [CrossRef]

40. Sfakiotakis, S. Study on the Exploitation of Agricultural, Urban and Industrial Wastes of Crete for Power Production-Thermal and Kinetic Analyses. Ph.D. Thesis, Technical University of Crete, Chania, Greece, 2016.

41. Stylianou, M.; Christou, A.; Dalias, P.; Polycarpou, P.; Michael, C.; Agapiou, A.; Papanastasiou, P.; Fatta-Kassinos, D. Ohysicochemical and structural characterization of biochar derived from the pyrolysis of biosolids, cattle manure and spent coffee grounds. J. Energy Inst. 2020, 93, 2063-2073. [CrossRef]

42. Shen, X.; Zeng, J.; Zhang, D.; Wang, F.; Li, Y.; Yi, W. Effect of pyrolysis temperature on characteristics, chemical speciation and environmental risk of $\mathrm{Cr}, \mathrm{Mn}, \mathrm{Cu}$ and $\mathrm{Zn}$ in biochars derived from pig manure. Sci. Total Environ. 2020, 704, 135283. [CrossRef]

43. IR Spectrum Table by Frequency Range; Merck kGaA: Darustadt, Germany, 2021.

44. Yuan, H.; Lu, T.; Wang, Y.; Chen, Y.; Lei, T. Sewage sludge biochar: Nutrient composition and its effect on the leaching of soil nutrients. Geoderma 2016, 267, 17-23. [CrossRef]

45. Yang, X.; Chang, K.; Kim, Y.; Zhang, J.; Yoo, G. Effects of different biochar amendments on carbon loss and leachate characterization from an agricultural soil. Chemosphere 2019, 226, 625-635. [CrossRef]

46. EBC. European Biochar Certificate, Guidelines for a Sustainable Production of Biochar, Version 4.8; European Biochar Foundation: Arbaz, Switzerland, 2014.

47. Boostani, H.; Najafi-Ghiri, M.; Hardie, A.; Khalili, D. Comparison of Pb stabilization in a contaminated calcareous soil by application of vermicompost and sheep manure and their biochars produced at two temperatures. Appl. Geochem. 2019, 102, 121-128. [CrossRef] 